Syntax Fusion: Jurnal Nasional Indonesia

e-ISSN: 2775-4440

Vol. 1, No. 10, Oktober 2021

\title{
EFEKTIVITAS PEMUNGUTAN PAJAK KENDARAAN BERMOTOR KENDARAAN DINAS DALAM MENINGKATKAN PAJAK ASLI DAERAH
}

\author{
Ahmad Rosandi Sakir, Rhayza Hayuarsi Sekar Sagita, Arni Samsir \\ STISIP 17-8-1945 Makassar, Indonesia \\ Email: ahmadrosandi8@gmail.com, sekarmakkii@gmail.com, \\ arnisamsir120@gmail.com
}

\begin{abstract}
Abstrak
Pajak Kendaraan Bermotor (PKB) merupakan salah satu sumber pendapatan asli daerah dan telah memberikan kontribusi yang signifikan terhadap pembiayaan dan pembangunan pemerintah di setiap daerah. Semakin besar jumlah kendaraan yang ada di setia daerah maka semakin besar peluang untuk menyumbang penerimaan di setiap Daerah. Selain Kendaraan Pribadi, kendaraan Umum dan Kendaraan Dinas juga tidak luput dari kewajiban pembayaran Pajak Kendaraan Bermotor. Jumlah penerimaan Pajak Kendaraan Bermotor Kendaraan dinas di suatu daerah berbanding lurus dengan jumlah kendaraan dinas yang ada pada suatu daerah. Kendaraan dinas ditandai dengan plat berwarna merah dan besar Nilai Pajak Kendaran Bermotor lebih rendah dibanding dengan kendaraan pribadi dan kendaraan umum. Metode penelitian adalah deduktif kualitatif. Responden adalah kepala UPT Pendapatan Maros dan Bagian Aset Pemda Maros. Hasil penelitian ini menjelaskan bahwa penerimaan pajak kendaraan dinas di kabupaten Maros belum Efektif dibuktikan dengan masih banyaknya tunggakan terhadap kendaraan dinas milik pemerintah yang belum.
\end{abstract}

Kata kunci: Pajak Kendaraan Bermotor; Kendaraan Dinas; efektifitas

Diterima: 24-09-2021 Direvisi: 14-10-2021 Disetujui: 18-10-2021

\section{Pendahuluan}

Pajak merupakan salah satu sumber penerimaan negara yang ditujukan untuk membiayai pengeluaran atau kebutuhan negara yang berkaitan dengan pembangunan negara. Menurut Rochmat Soemitro, pajak adalah iuran rakyat kepada perbendaharaan menurut undang-undang yang dapat dipaksakan tanpa jasa timbal balik yang dapat langsung ditunjukkan dan digunakan untuk menutupi biaya overhead.

Pajak juga merupakan pungutan yang dapat dipungut oleh pemerintah atas dasar undang-undang perpajakan dan sebagai wujud partisipasi masyarakat atau wajib pajak dalam pemenuhan kewajiban perpajakan secara langsung dan bersama-sama yang diperlukan untuk membiayai negara dan pembangunan negara. Tujuan pembangunan 
nasional adalah mewujudkan masyarakat adil dan makmur dengan meningkatkan taraf hidup kaum intelektual dan kesejahteraan seluruh rakyat. Dalam pelaksanaan pembangunan nasional tidak dapat dipisahkan dengan pembangunan daerah, oleh karena itu untuk memperlancar pembangunan nasional diperlukan anggaran negara yang diperoleh dari pemungutan pajak daerah. Untuk itu, pemerintah terus menggali setiap potensi yang dapat dimanfaatkan untuk meningkatkan dan mengoptimalkan pendapatan daerah (Suseka, 2017).

Pelaksanaan otonomi daerah yang menitikberatkan pada daerah dan perkotaan, dimulai dengan penyerahan sejumlah kewenangan dari pemerintah pusat kepada pemerintah daerah masing-masing. Sumber pendanaan yang terpenting adalah sumber pendanaan yang dikenal dengan PAD (Pendapatan Asli Daerah). Pendapatan Asli Daerah adalah pendapatan asli daerah yang dikelola oleh suatu daerah untuk mendukung pelaksanaan otonomi daerah. Semakin besar peran Pendapatan Asli Daerah (PAD) dalam pendapatan daerah mencerminkan keberhasilan badan usaha atau tingkat kemampuan daerah dalam membiayai penyelenggaraan pemerintahan dan pembangunan (岡戸順一 et al., 2003).

Pajak Kendaraan Bermotor (PKB) yang paling banyak menyumbang pendapatan asli daerah (PAD) dan pada akhirnya akan mempengaruhi pendapatan daerah. Pajak Kendaraan Bermotor (PKB) memiliki potensi yang paling besar karena transportasi saat ini menjadi kebutuhan seluruh masyarakat. Transportasi merupakan kebutuhan dan kebutuhan dalam kehidupan sehari-hari masyarakat, karena mempermudah masyarakat dalam melakukan aktivitas sehari-hari (Ahmad, Romadhoni, \& Adil, 2020).

Transportasi saat ini berkembang pesat, tidak hanya transportasi umum, tetapi juga transportasi pribadi. Masyarakat saat ini memilih mobil pribadi untuk kemudahan dan efisiensi. Apalagi dengan kemudahan pemberian kredit dari banyak pihak, memudahkan warga untuk membeli mobil pribadi. Inilah salah satu faktor yang membuat pajak kendaraan bermotor lebih tinggi dari pajak provinsi lainnya (Susanti et al., 2020).

Badan Perpajakan Daerah (BAPENDA) Sulawesi Selatan sebagai salah satu instansi teknis di bidang pemungutan pendapatan daerah menjalankan kewenangan untuk mengelola dan memungut pendapatan daerah khususnya pemungutan 4 pajak provinsi sesuai dengan Undang-Undang Nomor 28 Tahun 2009 (Suseka, 2017). Dan untuk memudahkan masyarakat dalam membayar pajak kendaraan bermotor, setiap daerah telah membentuk Unit Pelaksana Teknis (UPT), seperti Kabupaten Maros di Sulawesi Selatan, (Nuriyanto, 2014).

Penerimaan Pajak kendaraan Bermotor di Kabupaten Maros di triwulan 2 tahun 2021 sangat baik utamanya dengan berbagai program unggulan yang telah dijalankan dengan baik. Namun yang menjadi kendala dalam penerimaan pajak kendaraan bermotor adalah minimnya penerimaan dari kendaraan dinas yang seharusnya pada triwulan kedua sudah terbayar sebanyak 50 Persen, namun pada akhir bulan Juni 2021, penerimaan masih pada angka 23 persen (Kurniawan, 2017).

Hal ini menjadi perhatian bagi pemerintah dalam hal ini UPT Pendapatan Maros untuk memaksimalkan penagihan terhadap kendaraan dinas, baik itu kepada ASN atau 
kepada bagian Aset Pemda Maros. Upaya upaya ekstra harus dilakukan agar target realisasi penerimaan pajak kendaraan bermotor dapat tercapai melalui pajak kendaraan dinas pemerintah kabupaten maros. (Kolaborasi et al., 2019).

Dalam artikel ini akan diulas faktor pendukung dan penghambat yang dirasakan UPT Pendapatan maros dalam melakukan penagihan dan pemungutan pajak kendaraan bermotor kendaraan dinas di Kabupaten Maros.

\section{Metode Penelitian}

Pendekatan yang digunakan dalam penelitian ini adalah deduktif kualitatif. Pendekatan ini dipilih karena berangkat dari sejumlah teori dan pilihan kualitatif, karena semua teori yang digunakan dalam penelitian ini tidak bermaksud untuk diuji tetapi sebagai pengarah dalam menentukan konteks dan fokus penelitian sedangkan. Jenis penelitian adalah Studi Kasus sebab penelitian ini dipilih karena peneliti ingin mengembangkan wawancara mendalam untuk menggambarkan proses pemungutan Pajak Kendaraan Bermotor Kendaraan dinas (Heckman, Pinto, \& Savelyev, 1967).

Lokasi penelitian ini dilakukan di Kabupaten Maros Sulawesi Selatan bertempat di Kantor SAMSAT Maros, di mana tempat ini merupakan tempat bagi wajib pajak untuk membayarkan Pajak Kendaraan Bermotor (PKB). Penelitian ini berlangsung mulai Bulan Januari 2021 sampai dengan Bulan Juni 2021.

Sumber data dari penelitian bersumber dari wawancara dan observasi langsung. Data wawancara diperoleh langsung dari informan dengan memakai teknik pengumpulan data berupa interview. Informan adalah orang-orang yang betul paham dan terlibat langsung dengan permasalahan penelitian. Sedangkan data yang diperoleh dari observasi langsung adalah pengamatan yang dilakukan terhadap objek di tempat terjadinya suatu peristiwa.

\section{Hasil dan Pembahasan}

Penerimaan pajak daerah, khususnya pajak kendaraan bermotor, harus meningkat. Hal ini dikarenakan penggunaan kendaraan pribadi juga semakin meningkat dari tahun ke tahun, namun dalam proses pengelolaan pajak kendaraan di UPT Penerimaan Maros juga harus ada bea cukai dan program yang dijalankan juga efektif agar penerimaan juga bisa optimal.

Setiap pegawai Satker Maros diharapkan dapat berperan aktif dalam menjalankan tugas dan fungsinya untuk memastikan program-program yang ada berhasil, dan beberapa program juga dilaksanakan setiap tahunnya. Melihat banyaknya peran yang harus dipenuhi oleh seluruh pimpinan dan pegawai UPT Pendapatan Maros dalam menjalankan tugasnya, teori peran dapat diterapkan untuk menganalisis setiap hubungan dalam interaksi sosial yang melibatkan beberapa elemen baik dari mitra maupun masyarakat wajib pajak. Dalam praktiknya, kehidupan nyata seseorang menghadapi berbagai peran yang harus dipenuhi (Robbins \& Judge, 2008). Setiap peran yang dijalankan akan menjadi berbeda. Hal ini bergantung pada tugas pokok dan fungsi masing-masing dan berpengaruh pada penerimaan pajak kendaraan bermotor (Sakir, Yunus, \& Syamsu, 2021). 
Kendaraan negara atau kendaraan perusahaan juga tidak dibebaskan dari kewajiban membayar pajak kendaraan bermotor, kendaraan perusahaan ditandai dengan plat merah pada Nomor Kendaraan Bermotor (TNKB). Namun, besaran tol untuk kendaraan perusahaan lebih rendah dibandingkan dengan kendaraan umum dan pribadi.

Kendaraan dinas dibayar oleh pemerintah melalui Kantor Aset, yang tagihannya dikeluarkan oleh Pengelola Pendataan dan Pendataan Maros. Maka diperlukan komunikasi yang sangat baik antara UPT Penerimaan Maros dengan pemerintah daerah agar penerimaan pajak dapat optimal sebagaimana dilansir $\mathrm{S}$ dalam kutipan wawancara di bawah ini.

"Mengenai randis, kami banyak berkomunikasi dengan pemerintah kota tentang pembayaran randis setiap bulan karena masih banyak kendaraan perusahaan yang tidak membayar pajak. Bahkan dalam pelayanan mobil dinas yang dijalankan oleh pemerintah daerah, kami dari Bappenas juga hadir saat pengecekan pajak kendaraan bermotor yang digunakan oleh pegawai pemerintah daerah"

Sementara itu, dalam pernyataan otoritas Kabupaten Maros tentang Pembayaran Pajak Randis, HN muncul, yang menyatakan bahwa:

"Masalah utamanya beberapa pegawai membayar pajak langsung ke Samsat dan tidak melalui kami, sehingga database yang kami miliki terkadang tidak sesuai dengan tagihan Samsat. Kami sudah berkali-kali menyatakan bahwa pembayaran pajak harus melalui kami terlebih dahulu dan kemudian kami akan mengeluarkan sertifikat."

Dari hasil koordinasi antara UPT Pendapatan Maros dan Pemda dihasilkan pajak kendaraan bermotor kendaraan dinas sesuai dengan data di bawah ini:

Tabel 1

\begin{tabular}{|l|l|l|}
\hline NO & \multicolumn{1}{l}{ BULAN } & \multicolumn{1}{l}{ PENERIMAAN } \\
\hline $\mathbf{1}$ & \multicolumn{1}{l}{ JANUARI } & 21.385 .250 \\
\hline $\mathbf{2}$ & FEBRUARI & 18.351 .000 \\
\hline $\mathbf{3}$ & MARET & 41.258 .360 \\
\hline $\mathbf{4}$ & APRIL & 26.368 .200 \\
\hline $\mathbf{5}$ & MEI & 11.560 .500 \\
\hline $\mathbf{6}$ & JUNI & 17.700 .800 \\
\hline \multicolumn{1}{|l}{ TOTAL } & 136.624 .110 \\
\hline
\end{tabular}




\section{Penerimaan PKB Kendaraan Dinas Januari Sampai Juni 2021}

Dari data di atas penerimaan pajak kendaraan bermotor kendaraan dinas juga sangat besar, sampai bulan Juni 2021 berjumlah 136 juta, hasil ini sangat membantu dalam pencapaian target. Namun dengan jumlah tersebut belum mampu merealisasikan target penerimaan, jumlah yang seharusnya diterima sampai bulan Juni 2021 adalah senilai Rp 361.780.000. Hal ini tentunya menjadi bahan evaluasi bagi UPT Pendapatan Maros dalam menggiatkan tagihan terhadap Pajak Kendaraan Bermotor Dinas. Adapun hal yang menjadi Faktor pendukung dan Faktor Penghambat dalam penerimaan Pajak Kendaraan Bermotor Kendaraan dinas di Kabupaten Maros adalah sebagai Berikut

\section{Faktor Pendukung}

Faktor pendukung (Ratnasari, 2016) adalah faktor yang memfasilitasi perilaku individu atau kelompok termasuk keterampilan. Faktor ini meliputi ketersediaan, keterjangkauan sumber daya pelayanan. Terkait dengan penerimaan pajak kendaraan bermotor, Faktor pendukungnya adalah segala hal yang mendukung untuk pemenuhan pemungutan pajak kendaraan bermotor. Adapun faktor pendukung Penerimaan Pajak Kendaraan Bermotor adalah sebagai berikut:

\section{Potensi Besar di Kabupaten Maros}

Banyaknya kendaraan bermotor yang ada di Kabupaten Maros merupakan suatu peluang besar bagi Pemerintah untuk mendapatkan penerimaan Pajak Kendaraan Bermotor. Hal demikian juga berlaku bagi kendaraan dinas dimana jumlah potensi kendaraan dinas yang ada di Kabupaten Maros adalah sebanyak Rp. 3.653.829.380. Jika dengan potensi tersebut bisa dimaksimalkan maka Pajak Kendaraan bermotor kendaraan dinas dapat menyumbang Pendapatan Asli Daerah yang tinggi bagi Kabupaten Maros.

2. Pelayanan Pembayaran yang Inovatif

Pembayaran Pajak Kendaraan Bermotor di Kabupaten Maros tidak hanya dapat dilakukan di Samsat Stasioner, tapi juga dapat dibayarkan pada gerai samsat keliling yang beroperasi di Kabupaten Maros. Hingga saat ini ada sekitar 7 titik gerai pelayanan yang tersebar di beberapa tempat di Kabupaten Maros. Hal ini memudahkan masyarakat dalam membayar pajak kendaraan bermotor sehingga berpeluang untuk mengoptimalkan penerimaan pajak kendaraan bermotor.

\section{Faktor Penghambat}

1. Kurang Koordinasi antara UPT Pendapatan dan Pemda

Yang menjadi kendala utama dari kurang optimalnya penerimaan pajak kendaraan bermotor Kendaraan Dinas adalah kurangnya koordinasi antara UPT Pendapatan dan Pemda Maros, seringkali surat tagihan yang diberikan kepada Pemda untuk pembayaran Pajak Kendaraan Bermotor Kendaraan Dinas diabaikan dan proses pembayarannya pun cenderung lama.

2. ASN yang tidak Patuh dan Abai

Kesadaraan ASN yang menggunakan kendaraan dinas untuk melaporkan Pajak Kendaraan Bermotor dinilai sangat tidak patuh, hal ini dibuktikan dengan banyaknya Pajak Kendaraan Dinas yang menunggak. 
Ahmad Rosandi Sakir, Rhayza Hayuarsi Sekar Sagita, Arni

\section{Kesimpulan}

Efektivitas Penerimaan Pajak Kendaraan Bermotor Kendaraan Dinas di Kabupaten Maros sangat bergantung pada faktor pendukung dan faktor penghambat. Faktor pendukung Penerimaan Pajak Kendaraan Bermotor adalah potensi yang besar di Kabupaten Maros serta pelayanan pembayaran yang inovatif. Sedangkan untuk faktor penghambatnya adalah kurangnya koordinasi antara UPT Pendapatan Maros dengan Pemda Maros dalam hal ini bagian aset pemda Maros, serta ASN yang menggunakan kendaraan dinas yang tidak patuh dan taat terhadap Pajak Kendaraan Bermotor 


\section{BIBLIOGRAFI}

Ahmad, B., Romadhoni, B., Adil, M., \& Makassar, U. M. (2020). Efektivitas Pemungutan Pajak Kendaraan Bermotor. Jurnal Riset Perpajakan, 3(1), 15-23. Google Scholar.

AR Sakir, A. R. (2021). Budaya Birokrasi: Kinerja Pegawai Samsat Maros dalam Pelayanan Pembayaran Pajak Kendaraan bermotor. 7, 25-35. https://journal.lldikti9.id/sosiosains/article/view/573/402 Google Scholer.

Heckman, J. J., Pinto, R., \& Savelyev, P. A. (1967). 済無No Title No Title No Title. Angewandte Chemie International Edition, 6(11), 951-952., 3(1), 685-694. Google Scholar.

Kolaborasi, I., Daerah, P., Pihak, D., Produksi, T., \& Kelapa, P. (2019). Jurnal Sosio Sains. 5, 108-114. Google Scholar.

Kurniawan, R. C. (2017). Inovasi Kualitas Pelayanan Publik Pemerintah Daerah. FIAT JUSTISIA:Jurnal Ilmu Hukum, 10(3), 569-586. Google Scholar.

Nuriyanto, N. (2014). Penyelenggaraan Pelayanan Publik Di Indonesia, Sudahkah Berlandaskan Konsep "Welfare State"? Jurnal Konstitusi, 11(3), 428-453. Google Scholar.

Ratnasari, Nempung, T., \& Suriadi, L. O. (2016). Analisis Penerimaan Pajak Kendaraan Bermotor Di Provinsi Sulawesi Tenggara. Jurnal Progres Ekonomi Pembangunan, 1(1), 82-95. Google Scholar.

Susanti, N., Cania, S., \& Rosya, N. (2020). Strategi Peningkatan Kepatuhan Wajib Pajak kendaraan Bermotor di kantor Samsat Painan. Jurnal Ecogen, 3(2), 344. Google Scholar.

Suseka, S. (2017). Penerimaan Pajak Kendaraan Bermotor (Studi Kasus pada Kantor Unit Pelayanan Pendapatan Daerah Sintang). JURNAL PEKAN: Jurnal Pendidikan ..., 2(1), 44-62. Google Scholar.

TBSA. (2014). No 主観的健康感を中心とした在宅高齢者における 健康関連指標に 関する共分散構造分析Title. 634. https://hsgm.saglik.gov.tr/depo/birimler/sagliklibeslenme-hareketli-hayat-db/Yayinlar/kitaplar/diger-kitaplar/TBSA-BeslenmeYayini.pdf. Google Scholar. 